Problemy Drobnych Gospodarstw Rolnych • Nr 2 • 2019, 87-94

Problems of Small Agricultural Holdings • No. 2 • 2019, 87-94

\title{
Fruit and vegetable consumption in Hungary regarding qualification and incomes
}

\section{Spożycie owoców i warzyw na Węgrzech w zależności od wykształcenia i dochodów}

\author{
Imola Szabó, József Lehota
}

Szent István University, Hungary

\begin{abstract}
This study presents the how income and the qualification influence the fruits and vegetables consumption in Hungary. According to several researches it can be seen, consumers with higher education level and salary eat healthier and variable. There are a lot of students who live on higher living standards because their parents can help them with their higher incomes. In the case of fruits and vegetables consumption income and qualification are very important factors. Highly qualified consumers spend and eat more fruits and vegetables than lower qualified consumers. The diversity is significant, and the structure of fruits and vegetables consumption is differentiated. Calculating with data of Hungarian Central Statistical Office we showed the Hungarians' fruits and vegetables consumption habits regarding their qualification and income. The connection between income, qualification, and fruits and vegetables consumption is remarkable. It is clearly seen, people can choose a better and healthy life only with higher qualification and income.
\end{abstract}

Keywords: fruits and vegetables, qualification, income, consumption, food expenditures

Streszczenie. Celem badania jest pokazanie, w jaki sposób dochód i wykształcenie wpływają na spożycie warzyw i owoców na Węgrzech. Dotychczasowe badania wykazały, że konsumenci o wyższym poziomie wykształcenia i wyższych dochodach jedzą zdrowiej i lepiej. Studenci zazwyczaj żyją na wyższym poziomie życia, który mogą im zapewnić rodzice ze względu na ich wyższe dochody. W konsumpcji owoców i warzyw bardzo ważne są dochody i wykształcenie. Konsumenci o wyższych kwalifikacjach wydają więcej na żywność, warzywa i owoce w porównaniu z konsumentami o niższych kwalifikacjach. Różnica jest znacząca, a także zauważalna różnica w jakości. Do naszych obliczeń wykorzystaliśmy dane Węgierskiego Głównego Urzędu Statystycznego do przedstawienia węgierskich nawyków konsumpcji owoców i warzyw według wykształcenia i dochodów.

Corresponding Authors - Adres do korespondencji: Imola Szabó, PhD student, Doctoral School of Management and Business Administration, Szent István University, Faculty of Economics and Social Sciences H-2100 Gödöllő, Páter Károly street 1, e-mail: 1.szabo.imola@gmail.com 
Istnieje niezwykła korelacja między dochodami, wykształceniem a konsumpcją warzyw i owoców. Oczywiste jest, że tylko ludzie z wyższym wykształceniem i wyższymi dochodami mogą żyć lepiej i zdrowiej.

Słowa kluczowe: owoce i warzywa, kwalifikacje, przychody, spożycie

JEL: D31, E21, J31

\section{Introduction}

Many scientific studies, recommendations, and promotional programs pay people's attention for the importance of daily fruits and vegetables consumption. Despite of endeavor people do not eat enough fruits and vegetables around the world. This is the global problem, excluding some good examples, for instance South European countries, but habitants of many countries choose convenience foods instead of healthy diet. This is due to lifestyle which changes difficultly and slowly. The income affects deeply for lifestyle and the education level also influences it. After the crises the incomes have been increasing continuously in Hungary, but there are significant differences between them. There are also significant differences between eating habits of customers, especially for fruits and vegetables. Our goals to show how the income and the qualification affect for fruits and vegetables consumption in Hungary, and how the education links to the income and changes the food choice and healthy diet.

\section{Aim and method}

This study is written by the aim to present how the qualification and the income of consumers influence the fruits and vegetables consumption. Our hypothesis is the income and the qualification deeply affect - for fruits and vegetables consumption. Examining the connection we analyzed several previous studies in connection with this topic, and results of previous representative surveys which were conducted in Hungary, and made many calculations and comparisons to show the Hungarian issue. We worked with data of Hungarian Central Statistical Office (KSH), from 2010 to 2017 years, and compared them to show more aspects of connection. We used charts to represent our results and show the correlation between the examined factors.

\section{Income, qualification and consumption of fruits and vegetables}

It is a well-known fact that incomes affect to purchase, and are important roles in buying decision. The "Hierarchy of food choices" pyramid (Fig. 1), which follows Maslow's pyramid, shows how increasing incomes change the food choice and how the food choice changes from nutrition to status. In the case of lower income, the foods 
are nutritious, safe and cheap. These indicators are on the lowest level of pyramid. On the next level, the taste of foods becomes important. On the middle of pyramid the convenience and the variety are more significant factors in the case of purchase, where the income is average or higher than average. In terms of higher income the most important attribution of foods is improving the health. On the top of the pyramid where the income is the highest, the foods become status' social cause (Armbruster and Knutson, 2013). The function of food is changed by growing income.

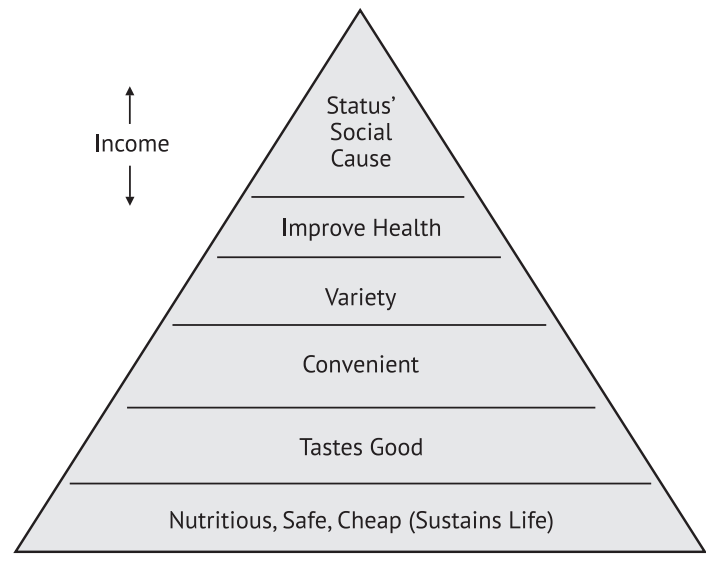

Fig. 1. Hierarchy of food choices

Source: Armbruster and Knutson (2013)

According to a representative survey in Hungary, was conducted in 2009, the highly educated consumers choose foods more consciously than consumers with lower education. In the case of food choice awareness there is significant difference between them as well as in terms of knowledgeability (Brávácz, 2010).

Szakaly et al. had conducted research which shared the Hungarian customers in different clusters regarding their lifestyle. As results showed the "rational" customers are $9,2 \%$ of the all population, and the "adventurous" customers are $43 \%$ of the all population. More of them said they have eaten healthy for many years and their health awareness is higher than the customers of other clusters. The majority of the "rational" customers are highly educated women with higher salary. They choose foods consciously and draw their attention for label and information about products. They are open for novelty and prefer the fresh products. The "adventurous" cluster is the biggest, including a lot students and housewives which refer for high number of young people of cluster. The women are overrepresented. Their incomes are on average level as well as their qualifications. They are interested in label, knowing more information about products, open for novelty, and prefer more the benefit of products than enjoyment (Szakaly et al., 2012). It can be seen the customers of these two clusters have many common characteristics; highly educated women with higher salary, and educated young people (including students) living in a family with average income, 
who pay more attention for healthy diet, choose products more consciously, and have higher awareness in connection with healthy life and healthy diet.

According to a representative survey about health in Hungary, was conducted in 2009, showed how the income influences choosing healthy diet. Besides many new and useful results, it showed the richest people are $6 \%$ of the all population, and the poorest are $31 \%$ of the all population. While $28 \%$ of the richest eat very consciously, just $4 \%$ of the poorest eat similarly. The research found the incomes, the qualification, and the cultural habits also affect for eating habits (Lantos, 2010).

Rácz (2013) found the LOHAS (Lifestyle of Health and Sustainability) segment in Hungary is approximately $8 \%$ of the all population. They are interested in healthy life, healthy diet, environmental protection, and sustainability. This segment is part of the "trend followers", who are mostly higher educated people with high salary, youngsters (15-24 ages) are overrepresented, including a lot of students, and live in the capital or bigger cities. This research also presented how education and income affect for eating habit, especially healthy diet.

Tárki Social Research Institute Inc. and Gfk Hungary Market Research Company were conducted a representative joint research to make segments of the Hungarian population regarding their consumption. They could create eight consumer segments. The lifestyle of segments based on their consumption behavior. The examined dimensions of their consumption were: quality of housing, material goods, foods and clothing, culture, information technology, and finance. In connection with this topic we just show the first four segments' characterization; the "upper plus", the "top classic", the "successful intellectuals", and the "hedonistic youngsters". The "upper plus" segment is $4 \%$ of the sample, includes mostly youngster (14-30 ages), with a lot of (university) students beyond a plenty of highly educated (university or college degree) people. In the case of university students their parents ensure the conditions of high level of their lifestyle, especially the finance. It means the members of segment have high income. The group is typified by varied food consumption and out-of-home-dining. The "top classic" is $2 \%$ of the sample. They are typified by the same traits than the "upper plus". They are highly qualified people with university or college degree with a high income, and there are a lot of students. They eat diversely and out-of-home many times. The "successful intellectuals" is $14 \%$ of the sample. Their consumption is very similar than the "upper plus", but on lower level. The "hedonistic youngsters" are 17\% of the sample. Their income levels are similar than the "top classic's". In these two groups the most number of people living in the same household, which is one of the causes of high occurrence rate of students. In this group there are a lot of people with just secondary school degree (graduation). They eat varied foods but consume a plenty of basic foods. One of the most characteristic feature is the over consumption, because many times they consume more from everything than their opportunities allow. The members of other four segments have lower income and qualification which affect for their consumption. They cannot eat varied foods and the level of their consumption is lower than the first four segments. As consequently, the income and the education are very important key factors in consumption, because the highly educated people with high income or/and (university) students with their parents' incomes can choose healthy and varied foods. 
There is no opportunity to choose a better and healthy life without money, and the education is also influence deeply for food choice (Keller, 2008).

Hungarian Academy of Sciences and Gfk Hungary Market Research Company were conducted a joint research in 2014 about structure of Hungarian population which based on Bourdieu's theory of capital: the economic capital, the social capital, and the cultural capital. The "elite" (2\%), the "upper middle" (10,5\%), the "emerging youth" (6\%), the "rural intellectuals" (7\%) are on the top of the Hungarian society. They are highly educated people; most of them have university or college degree or at least secondary school degree. They have high income. In the case of this topic, it is need to emphasize that the "emerging youth" ranks third in the order, they use their parents' incomes, but they can become the members of higher classes in the future because of their talents and social networks. This research also showed how money and education affect for lifestyle, consumption, social stratification, and the future of people (Róbert, 2014; Róbert, 2015).

\section{How do statistical data figure the Hungarian issue?}

At calculations we followed the WHO's recommendation that the fruits and vegetables consumption does not include potatoes (WHO).

Examining the data of Hungarian Central Statistical Office (KSH) it can be seen that there is significant difference between expenditures regarding the income. Customers who belong to the tenth income deciles spend almost fivefold for fruits and triple for vegetables on average than who have the least salary. In the case of consumption they consume more than triple fruits and twofold vegetables (KSH/a,b). As consequence, the income is a key factor in terms of fruits and vegetables consumption. After the crises the Hungarian salaries have been increasing continuously, but despite it there is remarkable disparity between incomes of highly educated consumers and incomes of low educated consumers. While the highest educated consumers had income sixfold than the lowest educated consumers in 2010, this disparity reduced to triple in 2017. Customers with high school degrees are in better position than whom without at least secondary school degrees, but people with college or university degrees are in the best position regarding incomes $(\mathrm{KSH} / \mathrm{c})$. As the incomes change, the structure of fruits and vegetables intake also modifies. For instance, the low qualified people eat less citrus fruits and tropical fruits than the highly educated people. Consequently, highly educated people consume more import products. They consume significantly more peach, melons, and berries. In contrast they eat less onion, parsley and carrot, but more tomato, sweet pepper, mushroom, and canned vegetables. It is need to mention that the potato intake is almost twofold in the case of low qualified consumers than in terms of highly qualified people $(\mathrm{KSH} / \mathrm{d})$.

There is bigger difference in the case of fruits intake than in terms of vegetables consumption. As Figure 2 shows highly educated consumers eat more fruits and vegetables than lowest educated consumers. The presented data by charts includes all fruits and vegetables excluding potatoes following WHO/FAO recommendation.

The Figure 3 shows how the qualification of customers influences their expenditures. It clearly seems highly educated customers spend more for fruits and vegetables 


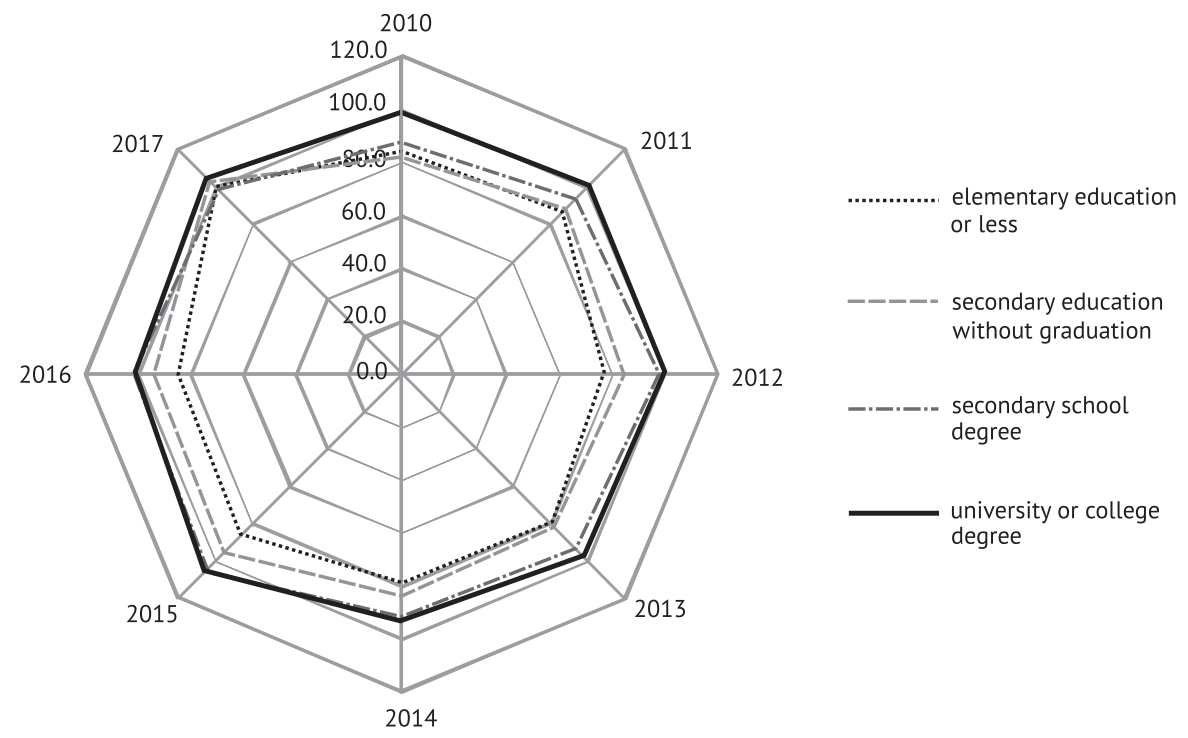

Fig. 2. Annual fruits and vegetables consumption in Hungary between 2010 and 2017, regarding consumers' qualification, counted in kilogram

Data source: $\mathrm{KSH} / \mathrm{d}$
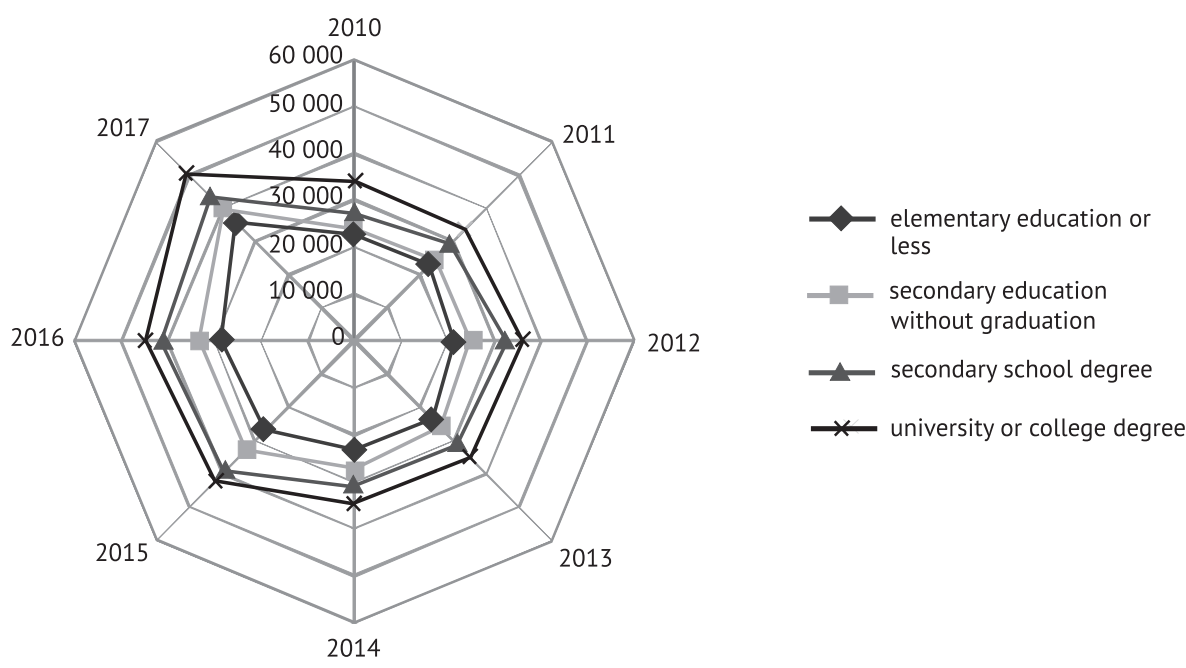

Fig. 3. Annual fruits and vegetables expenditures regarding consumers' qualification between 2010 and 2017, counted in Hungarian currency (HUF)

Data source: $\mathrm{KSH} / \mathrm{e}$ 
than who have lower qualifications. Customers with university or college degree almost spend twice as much as customers with elementary or less education. Each completed qualification give a chance to can spend and eat more fruits and vegetables, that choosing a better and healthy life and diet.

The examined data show the qualification determines the income and these two factors together deeply determine the fruits and vegetables expenditures and consumption. There is no chance for varied diet without high or higher education and higher income. As consequence, for choosing healthy life and diet need to study and obtain a higher qualification. The education is really important and influencing factor in the case of fruits and vegetables consumption, and with higher qualification customers have a chance to get higher salary. With these two factors having a chance for a better and healthy life.

\section{Conclusions}

In our study we presented how the income and the qualification affect for fruits and vegetables consumption. Our hypothesis is confirmed that these two factors deeply influence for fruits and vegetables intake. Many previous researches showed that highly educated people have higher income, and they can choose the healthy life and eat healthier. Their results also showed that the students can live on higher living standard because of their parents' salary. Their better lifestyles are found by their parents. Therefore they have a chance for better and healthy life. As our calculations presented highly qualified people spend and eat more fruits and vegetables than lower qualified people. Consequently, the high income and the education are together influence significantly for fruits and vegetables intake mostly. Moreover, it can be seen that there is correlation between high qualification and higher income. As results show, it is worth to learn and need to do getting higher income. People can choose a better life just after it.

\section{References}

Armbruster, W.J., Knutson, R.D. (eds.) (2013): US Programs Affecting Food and Agricultural Marketing. Springer, New York, 28-35.pp.

Brávácz, I. (2010). “Ưjuló” vásárlási szokások, azaz mennyire vagyunk tudatos étkezők? MOK, Budapest. https://emok.hu/tanulmany-kereso/d119:ujulo-vasarlasi-szokasok-azaz-mennyire-vagyunk-tudatos-etkezok [Accessed: 08 August 2019].

Keller, T. (2008). Fogyasztói szegmentáció. http://old.tarki.hu/hu/research/gazdkult/fogyasztoi_szegmentacio.pdf [Accessed 15 Aug 2019].

$\mathrm{KSH} / \mathrm{a}$. Az egy före jutó éves kiadások részletezése COICOP-csoportosítás, jövedelmi tizedek (decilisek), régiók és a települések típusa szerint (2010-) http://www.ksh.hu/docs/hun/xstadat/xstadat_eves/i_zhc021a.html [Accessed 12 Aug 2019].

KSH/b. Az egy fơre jutó éves élelmiszer-fogyasztás mennyisége jövedelmi tizedek (decilisek), régiók és a települések típusa szerint (2010-)* http://www.ksh.hu/docs/hun/xstadat/xstadat_eves/i_zhc023a.html?down=1794 [Accessed 12 Aug 2019]. 
$\mathrm{KSH} / \mathrm{c}$. Az összes háztartás adatai a referenciaszemély korcsoportja, iskolai végzettsége és a háztartástagok korösszetétele szerint (2010-) http://www.ksh.hu/docs/hun/xstadat/xstadat_eves/i_zhc015a.html [Accessed 12 Aug 2019].

$\mathrm{KSH} / \mathrm{d}$. Az egy före jutó éves élelmiszer-fogyasztás mennyisége a referenciaszemély korcsoportja, iskolai végzettsége és a háztartástagok korösszetétele szerint (2010-) http://www.ksh. hu/docs/hun/xstadat/xstadat_eves/i_zhc029a.html [Accessed 12 Aug 2019].

$\mathrm{KSH} / \mathrm{e}$. Az egy főre jutó éves kiadások részletezése COICOP-csoportosítás, a referenciaszemély korcsoportja, iskolai végzettsége és a háztartástagok korösszetétele szerint (2010-), http:// www.ksh.hu/docs/hun/xstadat/xstadat_eves/i_zhc027a.html [Accessed 12 Aug 2019].

Lantos, Z. (2010). Az egészséges és az egészségesnek gondolt táplálkozás trendjei. Élelmiszer, Táplálkozás és Marketing. VII. évf. 1, 37-40.

Rácz, G. (2013). Az értékek változásának és a fenntartható fejlődés trendjének hatása a hazai élelmiszerfogyasztásra. Doktori értekezés. Gödöllő. https://szie.hu/file/tti/archivum/Racz_ Georgina_ertekezes.pdf [Accessed: 30 March 2019].

Róbert, P. (2014). Osztálylétszám 2014,

https://politikatudomany.tk.mta.hu/uploads/files/Osztalyletszam2014_MTATK.pdf [Accessed 15 Aug 2019].

https://politikatudomany.tk.mta.hu/uploads/files/retegek_leirasa_nehany_fontos_adat.pdf [Accessed 15 Aug 2019].

Róbert, P. (2015). Osztály-és rétegződéskutatási dilemmák a magyar társadalomban. Replika, 92-93 (3-4. szám), 77-93.

Szakaly, Z., Szente, V., Kover, G., Polereczki, Z., Szigeti, O. (2012). The influence of lifestyle on health behavior and preference for functional foods. APPETITE, 58, 1, 406-413. DOI: 10.1016/j. appet.2011.11.003 http://apps.webofknowledge.com/full_record.do?product=WOS\&search_ mode $=$ GeneralSearch \&qid=4\&SID=E1 nZGYBNyHEMQoxUg6O \&page $=1$ \&doc $=4$ \& cacheurlFromRightClick=no [Accessed: 05 June 2019].

WHO. Promoting fruit and vegetable consumption around the world https://www.who.int/dietphysicalactivity/fruit/en/ [Accessed 29 May 2019].

Zaakceptowano do druku - Accepted for print: 27.12.2019

Do cytowania - For citation:

Szabo, I., Lehota, J. (2019). Fruit and vegetable consumption in Hungary regarding qualification and incomes [Spożycie owoców i warzyw na Węgrzech w zależności od wykształcenia i dochodów]. Problemy Drobnych Gospodarstw Rolnych - Problems of Small Agricultural Holdings, 2, 87-94. doi: DOI: http://dx.doi.org/10.15576/PDGR/2019.2.87 